\title{
IMPLEMENTATION OF MATHEMATIC VALUES OF KARAPAN SAPI'S MADURA WITH STAD LEARNING SETTINGS IN SDN PADEMAWU
}

\author{
Sri Indriati Hasanah ${ }^{1}$, Harfin Lanya ${ }^{2}$, Chairul Fajar Tafrilyanto ${ }^{\mathbf{3}}$ Zumrotun Aini $^{4}$ \\ ${ }_{1,2,3,4}$ Pendidikan Matematika,Universitas Madura, Pamekasan \\ 1indriati_math@unira.ac.id \\ 2lanya_math@unira.ac.id \\ 3 chairul_math@unira.ac.id \\ 4ainizumrotun@gmail.com
}

\begin{abstract}
Abstrak: Penelitian ini merupakan Penelitian Tindakan Kelas (PTK) di SDN Pademawu pada pokok bahasan bangun datar. Berdasarkan observasi di lapangan, guru mata pelajaran kurang mengaitkan konsep pembelajaran dengan kehidupan sehari-hari yang mana sangat berperan penting dalam proses penyerapan konsep yang dilakukan oleh siswa terutama budaya setempat dalam hal ini budaya karapan sapi. Maka dari itu perlu adanya implementasi nilai-nilai matematis karapan sapi Madura dengan setting model pembelajaran STAD (Student Teams Achievement Division). Penelitian ini dilakukan dalam dua siklus dengan masing-masing siklus melalui beberapa tahapan: perencanaan, pelaksanaan, observasi, dan refleksi. Hasil analisis data, dapat disimpulkan bahwa aktivitas siswa dari siklus I ke siklus II mengalami peningkatan dari rata-rata 2,82 menjadi 3,54 dengan kategori sangat baik, sedangkan respon siswa mengalami peningkatan dengan nilai angket respon siswa memiliki rata-rata 83,63\% menjadi 96,97\% dengan kategori positif. Kemudian berdasarkan hasil tes, data menunjukkan peningkatan dengan persentase $57,58 \%$ menjadi $90,91 \%$.
\end{abstract}

Kata kunci: implementasi, nilai matematis, karapan sapi, STAD

\begin{abstract}
This research is a Classroom Action Research (PTK) at SDN Pademawu on the subject of flat wakes. Based on field observations, subject teachers do not relate the concept of learning to everyday life which is very important in the process of concept absorption by students and local culture, in this case the culture of the cow karapan. Therefore, it is necessary to implement the implementation of the mathematical values of the Madura cow karapan by setting the STAD (Student Teams Achievement Division) learning model. This research was conducted in two cycles with each stage: planning, implementing, observing, and reflecting. The results of data analysis showed that student activity from cycle I to cycle II had increased from an average of 2.82 to 3.54 in the very good category. While the student response has increased with the value of the student response questionnaire having an average of $83.63 \%$ to $96.97 \%$ in the positive category. Then based on the test results, the data showed an increase in the proportion of $57.58 \%$ to $90.91 \%$.
\end{abstract}

Keywords: implementation, mathematical value, karapan sapi, STAD 


\section{Introduction}

Education in the Law of the Republic of Indonesia number 20 of 2003 Chapter I Article 1 concerning SISDIKNAS is a conscious and planned effort to create an atmosphere of learning and the learning process so that students actively develop their potential. A country can achieve progress if education in a country is of good quality. The high and low quality of education in a country is influenced by many factors, for example students, teachers, infrastructure, and also environmental factors. One of the environmental factors is school. School is the main means for students to acquire knowledge in the realm of formal education. Schools are teaching institutions for students under teacher supervision that are included in the formal education system which is generally compulsory in a country (Wikipedia, 2019).

In this context, the author will allude to a problem in one of the subjects that most students consider complicated, namely mathematics. This is evidenced by the existence of mathematics learning in some students who consider mathematics to be a difficult subject with complex formulas. One of the principles of learning mathematics is starting from easy to difficult, from simple to complex. The linkage of Mathematics learning with everyday life also plays an important role in the process of conceptual absorption by students. Therefore, we often encounter story questions related to everyday life so that students can more easily understand and understand the concept of a Mathematics learning material because they often encounter this.

Based on the observations that researchers have made in one of the elementary schools in Pamekasan
Regency, namely SDN Pademawu, to be precise in grade IV there are several factors that cause student activity and learning outcomes on the subject of flat shapes and multiplication of numbers which are somewhat less qualified. In addition to the fairly dense class quantity, there are 33 students, thus making student learning activities less optimal. This is inseparable from the participation of teachers who do not relate less mathematics to everyday life. In this case, our daily activities cannot be separated from local customs and culture. Especially the island of Madura which has a variety of cultures that are quite well known to foreign countries. D'Ambrosio (1985:45) explains that the goal of ethnomatematics is to do mathematics in a different way by considering the development of academic knowledge in different cultural sectors and societies..Likewise, the presence of cultural-nuanced mathematics (ethnomatematics) will make a very large contribution to mathematics learning, because formal education is a social institution that is different from the others so that it allows socialization between cultures (Zayyadi and Subaidi, 2017:35).

On the other hand, the application of mathematical concepts in everyday life has been widely applied to the application of mathematical concepts found in traditional games that teach children to be creative and interact socially. Social interaction in traditional games teaches the values of cooperation, sportsmanship, honesty and creativity (Zayyadi, et al, 2018:126). In line with this, Budiharto (in Hafsi and Hasanah, 2018:192) states that the concept of mathematics is born from the thinking of a group (culture) of society, who can use mathematical concepts to solve problems in their environment according to the level of 
culture they have. and can be developed to be used as a thinking tool in simplifying complex problems.

Based on the problems that the researcher has described above, the researcher implements the mathematical values of the Madura cow karapan in a classroom action by linking the concept of subjects, especially Mathematics with the surrounding culture, especially karapansapi. Djazifah, et al (2015:30) argue that the learning process is not enough to increase knowledge (through core subjects) alone, it must be equipped with creative-critical skills, strong character (responsible, social, tolerant, productive, adaptive). In addition, Khasanah and Wijayanti (2017:178) argue that education is an effort to transform cultural values in order to achieve progress both individually and in society. Therefore it is important to implement the mathematical values of a culture in the learning process. This is in line with traditional games that can be used as a starting point or context in making learning designs for elementary school children (Risdiyanti and Prahmana, 2018:9).

One of the Madura Cow racing fields is located in the village of Murtajih, automatically the residents are already familiar with one of these Madurese cultures. The racetrack in the Kerabhan Sape competition is rectangular with a length of about 100 meters and a width of 50 meters (Aini, et al, 2019:181).

In addition, the mathematical value of the Madura cow karapan is collaborated with the cooperative learning model, namely STAD (Student Teams Achievement Division), which refers to the concept of Slavin R., (2009: 143-163) in Affandi and Irawan (2013: 3-6) with steps steps, namely: (1) Presentation of the material, (2) Group activities, (3) Tests, (4) Calculation of individual development scores, (5) Giving group awards. Rakhman and Syatroh (2015:72) argue that the STAD cooperative learning model is a cooperative learning model that uses small groups with a heterogeneous number of members of each group of 45 students. This can have an important effect on students' learning processes and can increase their interest in learning. Purwanti, et al (2018:81) suggest that teachers will give assignments through worksheets and learning tools. Heterogeneous student grouping was carried out based on the pre-test results (a mixture of high, medium and low).

According to Yunita, W (2016:139) STAD is a team learning method that provides opportunities for students to solve problems in learning, develop skills, and help each other in groups. In line with this statement, Fitri and Alfianika (2019:458) suggest that the advantage of using the STAD type cooperative approach in this study lies in the ability to communicate with group members. With this ability, students with moderate and low abilities feel supported by high-ability students.

This adds to the tolerance between students to help each other in terms of learning so as not to feel competitive with each other to get the highest score, but can form good character in students. In accordance with the statement from Habsiah, et al. (2017), namely students use the Student Team Achievement Division (STAD) learning method because this method can be used to instill a character of tolerance for students themselves. Through the application of the STAD type of cooperative learning model, teachers can apply character education to the subject matter. Improved character education can be embedded in 
the teaching and learning process in the classroom.

\section{Research Methodology}

This type of research is Classroom Action Research (PTK). According to Arikunto (2010:129) Action research is a problem-solving strategy that utilizes real action in the form of an innovative development process that is "tried as you go along" in detecting and solving problems. This action research was conducted to increase the effectiveness of teaching methods, assign assignments to students, assessment and so on. In line with this, Yahya, et al (2013:120) argue that PTK is defined as a form of reflective study by the actor of action. These actions are carried out to increase the rational stability of their actions in carrying out daily tasks, deepen their understanding of the actions taken, and improve the conditions in which these learning practices are carried out.

By combining these three word boundaries, namely (1) research, (2) action, and (3) class, it can immediately be concluded that classroom action research is an examination of learning activities in the form of an action, which is deliberately raised and occurs in a class simultaneously.

\section{According to Arikunto} (2010:137) Classroom action research uses a model proposed by Kemmis and Mc Taggart. The CAR model in question describes the existence of four steps and their remedies, which are presented in the following chart.

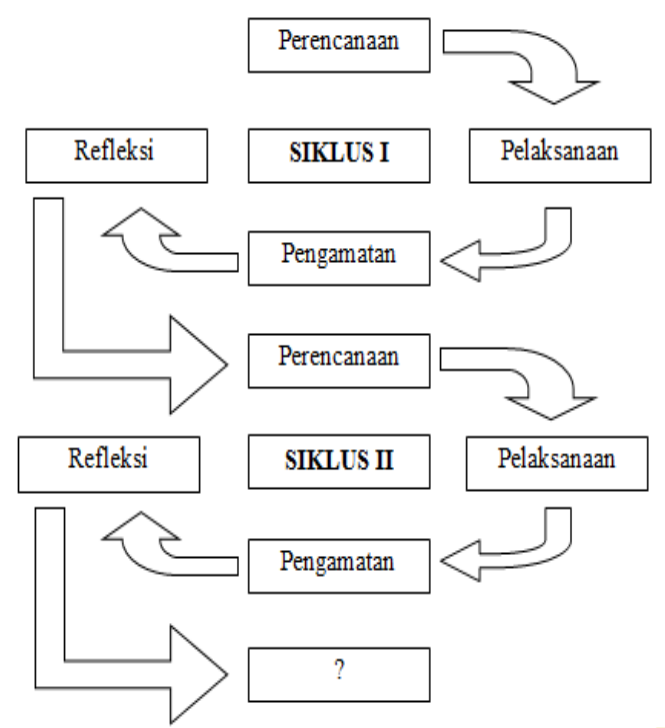

Figure 1. PTK cycle

This research was conducted in two cycles, each cycle through several stages: planning, implementing, observing, and reflecting. In each cycle, reflection is needed to evaluate the actions that have been taken. This is in accordance with Nilakusmawati, et al (2015:10) who argue that the results of reflection on the actions taken will be used again to revise the plan if it turns out that the actions taken have not succeeded in improving practice or solving problems that are of concern to teachers.

This research was conducted at SDN Pademawu, Pamekasan. While the research subjects were 33 grade IV students for the 2019/2020 academic year.

The instruments used in this study include the Learning Implementation Plan (RPP), Group Worksheets (LKK), Student Observation Sheets, Test Questions, and Student Questionnaires.

Data collection techniques carried out by researchers are: (1)Observation Methods, according to Arikunto (2010:272) in using the observation method, the most effective 
way is to complete it with a format or blank observation as an instrument. (2)The questionnaire, according to Arikunto (2010:194) states that the questionnaire is the number of written questions that are used to obtain information from respondents in the sense of reports about their personalities or things they know. The type of questionnaire used in this study was a closed questionnaire where the answers were provided, students only chose it. (3) The test is a series of questions or exercises that are used to measure the skills, knowledge, abilities or talents possessed by individuals (Arikunto, 2010:193).

Researchers used several data analysis techniques, namely: (1) Observation with formulas NA $=\frac{\sum n}{\sum a}$ (Arikunto, 2010: 76) and with the assessment category $0.00-1.49=$ less, $1.50-2.49=$ sufficient, $2.50-3.49=$ good, $3.50-4.00=$ very good. (2) Questionnaire with the formula The percentage of student responses $=\mathrm{A} / \mathrm{B}$ $\times 100 \%$ (Trianto, 2009:243). Student responses are said to be positive if the average percentage of students' answers is $60 \%$. While student responses are considered negative if the average percentage of students' answers is $<60 \%$. (3) Tests, in this study students' learning completeness was divided into two, namely: (a)Individual Learning Completeness with a value of $\geq 70$ (KKM Mathematics in SDN Pademawu). (b)Classical Completeness, in this case a class is said to be complete classically if at least $85 \%$ of the total students have completed individually.

\section{Results and Discussion Result}

The research was carried out based on the results of observations of the fourth grade homeroom teacher, which in their learning activities only applied direct learning and did not link learning with everyday life. Therefore, it is necessary to have research action to improve learning activities in the classroom. This is in line with the opinion of Subaidi and Lanya (2019:291) that it is necessary to reflect on these failures. Direct learning model causes a lack of students in thinking.

This study uses a scientific approach with one of the objectives is a learning process designed in such a way that students actively (identify problems or find problems), formulate problems, propose hypotheses (as a view of temporary answers before conducting analysis), analyze data, draw conclusions, and communicating the concepts, laws, or principles found (Hosnan, 2014:34). Yuliani, N (2019:9) argues that there are various types of learning approaches such as scientific approaches. This learning approach is in accordance with the characteristics of the implementation of the 2013 Curriculum in Indonesia.The application of the scientific approach to learning involves process skills such as observing, classifying, measuring, predicting, explaining, and concluding. Cycle I

The research in cycle I was held in 2 meetings and 1 meeting to test the learning outcomes. At the planning stage, researchers prepare learning tools such as Learning Implementation Plans (RPPs), Group Worksheets (LKK), Student Observation Sheets, Test Questions, and Student Questionnaires. At the first and second meetings, learning activities were carried out by applying the mathematical value of the Madura cow races in the STAD (Student Teams Achievement Division) learning model on the subject of 
determining the perimeter and area of square and rectangular shapes.

In the action stage of the first learning meeting, the researcher grouped students into 5 to 6 heterogeneous groups where the researcher distributed the LKK to each group to be discussed and then presented (observing and communicating). Student activity at the first meeting was still somewhat less active in communicating with the teacher in this case asking something that was not understood (ask) because it still felt foreign to the presence of researchers and observers at that time. However, at the second meeting there began to be a positive response from students to the presence of researchers (exploring).

In the observation stage, based on the data on student test results at the third meeting of the first cycle, students are said to be complete if the score is $\geq 70$. Guiding this, it can be seen that students who complete learning are 19 people, while students who do not complete learning are 14 people with an average the average student completed individually, namely 68,91 . Then for the percentage of classical learning completeness, namely $57,58 \%$ which is considered less fulfilling the completeness requirements of $85 \%$.

In the activity reflection or evaluation stage, many things must be fixed in the first cycle, especially the discovery of new problems, namely students who are less capable of multiplication count operations above the number 5. Therefore, in cycle II which will be carried out at the next meeting there will be improvements to the problem. Then in terms of activity there needs to be more interaction with students so that communication in the classroom is more enthusiastic. This is also influenced by the factor of how important the teacher is in understanding the learning methods and strategies in interactions with students. In line with this statement, Aini, SD, et al (2017:80) argue that the role and function of methods and strategies need to be understood by every teacher in the implementation of the learning process.

\section{Cycle II}

The research in cycle II was held in 2 meetings and 1 meeting to test the learning outcomes. At the planning stage, researchers prepare learning tools such as Learning Implementation Plans (RPPs), Group Worksheets (LKK), Student Observation Sheets, Test Questions, and Student Questionnaires.

In the action stage in cycle II, the researcher gives LKK to each group to be discussed and then presented (observing and communicating). There is a very significant difference from the first cycle, which at first was still hesitant to go forward and show the results of the discussion, in the second cycle, there were more groups who were enthusiastic in answering (reasoning). Then, the problem related to student weaknesses in the multiplication count operation above the number 5 has been resolved by the researcher by providing mathematical learning so that students find it easier to calculate the multiplication above 5 (explore).

At the observation stage, based on data on student test results in cycle II, students are said to be complete if the score is $\geq 70$. Guided by this, it can be seen that there were 30 students who had finished learning, while 3 students who did not complete their studies had completed their studies with an average of 84,67 students who had completed their studies. Then for the percentage of classical learning completeness that is $90,91 \%$ which is considered to have met the completeness requirements of $85 \%$. 
In the activity reflection or evaluation stage, there is quite a lot of improvement in learning activities both in terms of student attitudes who are very enthusiastic, student positive responses to learning and learning outcomes also increase based on the data obtained.

\section{Discussion}

Based on the results of observations made by researchers at SDN Pademawu, especially in grade IV, it is known that learning is more teacher-centered, while students tend to be passive. Teachers only stick to material handbooks such as textbooks and tend to apply direct learning without linking learning with everyday life. According to Hasanah and Saleh (2017:68), they argue that teachers are less able to implement curriculum changes properly which actually affects the quality of education, which is one of the factors that is important for teachers to actively interact with students by linking them to daily life. After reviewing the results of the classroom teacher interviews before the research action was carried out, the researcher as a teacher took action in cycle I and cycle II, namely by using mathematical values in the cow racing in the STAD (Student Teams Achievement Division) learning model on the subject of circumference and square area. and rectangle.This aims in addition to improving the quality of education quality and learning outcomes, researchers hope that this research is used as a reference so that the problems mentioned above do not become longterm problems. Because, according to Tafrilyanto and Kurnadi (2018:455) the low quality of graduates will also be a separate obstacle in the implementation of programs promoted by the government, in this case the Ministry of
Education and Culture which is caused by these problems.

Based on the results of learning management data using mathematical values in the cow racing with the STAD (Student Teams Achievement Division) learning model on the subject of circumference and area of rectangles and rectangles, this learning management turned out to be running smoothly and showed a positive result from cycle I until cycle II. Students' mathematics learning activities on the subject of the circumference and area of a square and rectangle in grade IV SDN Pademawu in this study increased by 0,72 from an average of 2,82 in the first cycle with the good category to 3.54 on the average in cycle II with very good category. While the student response has increased by $13,34 \%$ with the value of the student response questionnaire in the first cycle has an average of $83,63 \%$ in the positive category and in the second cycle it has an average of $96,97 \%$ in the positive category.

Individually and classically, there is an increase from cycle I to cycle II. In cycle I, 19 students were declared complete and 14 students were declared incomplete learning individually. For the classical test scores in cycle I have not reached the target of success, namely $57,58 \%$ of students who completed classically. In the second cycle, 30 students were declared complete and 3 students were declared incomplete learning individually. However, the improvement in cycle II produced significant results, namely $90,91 \%$. In cycle II it is said to be classically complete because the percentage obtained is $\geq 85 \%$. The increase from cycle I to cycle II was $33,33 \%$ of students who completed classically, thus all indicators of research success had been fulfilled in 
cycle II so that the implementation of the action was stopped until cycle II.

\section{Conclusions}

Based on the research data, students' mathematics learning activities on the subject of circumference and area of squares and rectangles in class IV SDN Pademawu in this study increased by 0,72 from an average of 2,82 in the first cycle with the good category to 3,54 . on the average in cycle II with very good category. While the student response has increased by $13,34 \%$ with the value of the student response questionnaire in the first cycle has an average of $83,63 \%$ in the positive category and in the second cycle it has an average of $96,97 \%$ in the positive category. Individually and classically, there is an increase from cycle I to cycle II. In cycle I, 19 students were declared complete and 14 students were declared incomplete learning individually. For the classical test scores in cycle I have not reached the target of success, namely $57,58 \%$. Whereas in cycle II, 30 students were declared complete and 3 students were declared incomplete learning individually. However, the improvement in cycle II produced significant results, namely $90,91 \%$ with an increase of $33,33 \%$, so that in the second cycle it was said to be classically complete because the percentage obtained was $\geq 85 \%$. Thus all indicators of research success have been fulfilled in cycle II so that the implementation of the action is stopped until cycle II.

Suggestions that can be taken from this research are: (1) For teachers who want to use the mathematical values of the cow race with the STAD (Student Teams Achievement Division) learning model on the subject of the circumference and area of squares and rectangles, it is suggested that they really understand and prepare carefully so that this learning can truly benefit students. (2) Researchers recommend that learning to use mathematical values in karapansapi to improve student learning outcomes, can be applied to other mathematics subjects, because this learning gets a positive response from students. (3) For readers, if you want to do research with the same problem, this thesis can be used as a reference journal. It is also intended that culturebased research that can be linked to learning can develop properly.

\section{References}

Affandi, M. dan Irawan, D. 2013. Pembelajaran Kooperatif Tipe Student Teams Achievement Division Di Sekolah Dasar. Semarang: Unissula Press.

Aini, S. D., dkk. 2017. Penerapan Metode Inquiry Dalam Pembelajaran Matematika Pada Pokok Bahasan Prisma, Interaksi : Jurnal Kependidikan.12(2): 80-3.

Aini, Z.,dkk. 2019. Etnomatematika: Eksplorasi Budaya Kerabhen Sape Madura. Journal of Medives, 3(2): 177-183.

Arikunto, S. 2010. Prosedur Penelitian: Suatu Pendekatan Praktik (Edisi Revisi 2010). Jakarta: Rineka Cipta.

Arikunto, S.,dkk. 2011. Penelitian Tindakan Kelas. Jakarta: Bumi Aksara.

D'Ambrosio, U. 1985. Ethnomathematics and its Place in the History and Pedagogy of Mathematics. For the Learning of Mathematics, 5(1): 44-48.

Depdiknas. 2003. (2019, October 24) Undang-undang RI No. 20 tahun 2003.Tentang Sistem Pendidikan Nasional. Retrieved fromhttps://kelembagaan.ristekdik 
ti.go.id/wpcontent/uploads/2016/0 8/UU-no-20-th-2003.

Djarifah, dkk. 2015. Analisis Implementasi Pendidikan Berbasis Budaya Pada Lembaga Pendidikan Non formal Di Daerah Istimewa Yogyakarta. Jurnal Penelitian Ilmu Pendidikan, 8(2): 28-38.

Fitri, R.danAlfianika, N. 2017.Effect of Student Teams Achievement Division and Vocabulary Mastery to Reading Comprehension Ability.Journal of Education and Learning, 11(4): 453-459.

Gayatri dan Wirakusuma, M. G. 2016. Penelitian Tindakan Kelas Untuk Meningkatkan Keterampilan Pembuatan Proporsal Penelitian Mahasiswa. E-Jurnal Akuntansi Universitas Udayana, 14(2): 1539-1554.

Habsiah, S., Effendi, Ridwan dan Mulyadi, A. 2017.The Effect Of Cooperative Learning Model Of Student Team Achievement Division (STAD) Type In Attempt To Improve Student Tolerance Character. International Journal - Pedagogy of Social Studies, 2(1): 1-5.

Hafsi, A.R. dan Hasanah, S.I. 2018. Kajian Etnomatematika Pada Rumah Adat Taneyan Lanjeng. Prosiding Silogisme Seminar Nasional Pendidikan Matematika Universitas PGRI Madiun, 1(1): 191-196.

Hasanah, S.I. dan Saleh, H. 2017. Pengembangan Perangkat Pembelajaran Matematika Berbasis Lesson Study Untuk Meningkatkan Profesionalitas Pendidik Di Daerah Tertinggal. Jurnal SIGMA, 2(2): 67-79.

Khasanah, K. dan Wijayanti, W. 2017. Strategi Implementasi Pendidikan Berbasis Budaya Dinas
Pendidikan Dasar Kabupaten Bantul. Jurnal Akuntabilitas Manajemen Pendidikan, 5(2): 174-188.

Nilakusmawati, dkk. 2015. (2020, August 23) Panduan Penelitian Tindakan Kelas, Universitas Udayana. Retrieved fromhttps://simdos.unud.ac.id/upl oads/file_pengabdian_dir/f166377 f1913726f4a67d7be6fa7eee9.pdf.

Purwanti, D., Musadat, Arif, A., dan Gunarhadi. 2018. Increasing Students' Achievement on Simple Two-Dimensional Figure Materials Through Students STAD for Third Graders of Elementary School. International Journal of Multicultural and Multireligious Understanding, 5(5): 80-86.

Rakhman, A. dan Syatroh, I. L. 2015. The Analysis Of Students' Team Achievement Divisions (STAD) Used In Learning Practice Of Translating And Interpreting, ELTIN Journal, 3(2): 72-84.

Risdiyanti, I. dan Prahmana, R. C. I. 2018. Etnomatematika: Eksplorasi Dalam Permainan Tradisional Jawa. Journal of Medives, 2(1): 111.

Subaidi, A. dan Lanya, H. 2019. Peningkatan Hasil Belajar Mahasiswa dalam Matakuliah Matematika Diskrit Melalui Model Student Teams Achievement Division (STAD). BRILIANT: Jurnal Riset dan Konseptual, 4(3): 289-297.

Tafrilyanto, C.F. dan Kurnadi, B. 2018. Pendekatan Realistik Mangrove untuk Meningkatkan Hasil dan Minat Belajar Siswa pada Pelajaran Matematika di SD Pesisir Sampang. BRILIANT: Jurnal Riset dan Konseptual, 3(4): 454-462. 
Trianto. 2009. Mendesain Model Pembelajaran Inovatif Progresif. Jakarta: Kencana Predana Media Group.

Wikipedia. 2019. (2020, January 13). Sekolah. Retrieved fromhttps://id.wikipedia.org/wiki/ Sekolah.

Yahya, dkk. 2013. Meningkatkan Hasil Belajar Siswa Kelas IV Mata Pelajaran PKn melalui Media Kliping di SD Inpres Despot Posona Kecamatan Kasimbar. Jurnal Kreatif Tadulako Online, 1(3): 118-130.

Yuliani, N. 2019. The Role of Student Teams Achievement Divisions (STAD) in Improving Student's Learning Outcomes. Classroom Action Research Journal,3(1): 815.

Yunita, Widia. 2016. Improving Students' Speaking Skill By Using Stad (Student Teams
Achievement Divisions). $A L$ ISHLAH: Jurnal Pendidikan, 8 (1): 136-153.

Zayyadi, M dan Subaidi, A. 2017. Eksplorasi Etnomatematika pada Batik Madura. Jurnal SIGMA, 2(2): 35-37.

Zayyadi, M., Hasanah, S.I., Surahmi, E. 2018. Ethnomatematics Of Exploration In Tradisional Games As A Form Of Student's Social Interaction. JIPM (Jurnal Ilmiah Pendidikan Matematika), 6(2): 125-132. 